\title{
EFFECT OF EARLY AGE HEAT STRESS ON GROWTH PERFORMANCE AND SOME BLOOD PARAMETERS OF TWO STRAINS OF RABBITS
}

\author{
Safaa E. Hashem ${ }^{1 *}$, El-Wardany ${ }^{1}$ I., Galal ${ }^{1}$ A. and Madkour ${ }^{2}$ M. \\ 1- Poultry Production Dept., Fac. of Agric. Ain Shams Univ., P.O. Box 68, Hadayek Shoubra \\ 11241, Cairo, Egypt \\ 2- Animal Production Dept., National Res. Center, Dokki, Giza, Egypt
}

*Corresponding author: Safaaezzat3@gmail.com

Received 11 October, 2019

Accepted 1 January, 2020

\begin{abstract}
The main objective of the present study was to evaluate the effect of short term Heat Stress on productive performance and some blood parameters in two strains of growing rabbits. A total number of 60 weaned unsexed rabbits (6 weeks of age) were used in this study (30 from each of New Zealand White, NZW, and Local Baladi Black, BB rabbits). They were randomly divided into two experimental groups: a control group and heat stressed one. The latter group was exposed to four hours of heat stress at $36 \pm 1{ }^{\circ} \mathrm{C}$ and $55-60 \% \mathrm{RH}$ for three consecutive days at 42 days of age. The same manner was applied after six weeks of age (at marketing). After HS exposure, three rabbits from each treatment were used to determine some blood parameters, heat shock protein (HSP 70, 90); Growth performance data were also recorded. Results showed that daily weight gain was significantly increased in heat stressed rabbits than control, while feed consumption was significantly reduced in NZW rabbits, resulting in an improvement in FCR of NZW rabbits than BB. Heat stress $(p \leq 0.05)$ increased plasma total protein, albumin and Globulin than control group, while $A / G$ ratio was not influenced. Baladi Black rabbits had significantly lower IGF and Corticosterone level compared by NZW rabbits, while T3 hormone level was not significantly affected. HS increased ( $p \leq 0.05$ ) IGF and Corticosterone levels. A significant interaction effect between HS and breed was recorded for all studied hormones. Heat shock protein were significantly increased in local BB rabbits compared to NZW ones. It is concluded that it is concluded that early age heat exposure of weaning rabbits could be used as an alternative tool to alle-
\end{abstract}

viate the negative impact of heat stress at older age. We chosen two strains of rabbits (BB, WZN) because they the most common types in our country.

Keywords: Heat stress, growth performance, HSP, blood parameters, rabbits

\section{INTRODUCTION}

In Egypt, rabbits production is faced with the problem of heat stress, especially during summer season, since, It is well known that rabbits are very sensitive to high environmental temperature (Sakr, 2005). Under heat stress conditions, rabbits use many strategies to alleviate the negative impact of heat load including reduction of feed intake, increase water consumption, modulation of thyroid gland function, regulation of body temperature and respiration rate, and also some physical and behavioral aspects (Marai et al 2001). Many Studies were conducted to investigate the productive potentialities of native and exotic breeds of rabbits under hot environmental conditions all reported a negative response of rabbits to different stressors but the degree of stress indices, differ between genotypes, humidity, air velocity and housing conditions (Abd El-Halim, 2003; Fernandez - Carmona and Cervera, 2010).

The comfort zone for rabbits was reported to be 15 to $20^{\circ} \mathrm{C}$, so rabbits can withstand cold weather than warmer one. The metabolic rate increased by about $20 \%$ in rabbits when exposed to high air temperature ranged from 30 to $35^{\circ} \mathrm{C}$ (Gonzalez et al 1971). It is well known that HS induce specific protein fractions to protect cells from different stressors. Since, Heat shock protein 70 (HSP 70) 
is a stress induced protein. It is an important part of the cell's machinery for protein folding. This protein acts as a molecular chaperone by binding to other cellular proteins, assisting intracellular transport and folding into the proper secondary structures, thus preventing aggregation of protein during stress (Hartl, 1996). Many Programs were during early age applied, to induce HSP by heat shock exposure to HS (at weaning or after kidding) as an alternative practice to increase thermos tolerance and acclimate rabbits to heat stress conditions which led to minimize heat- related mortality, improving productive performance and enhance immunity (Morai et al 1996). Exposure of rabbits to heat stress conditions during the growing period led to induce HSP70 protein family which acts as chaperone that assists in the folding, transport and assembly of protein in cytoplasm, mitochondria, and endoplasmic reticulum or it appears to play a critical role in protecting cells against the adverse effects of hyperthermia (Morimots et al 1990). Therefore, the present study was conducted to evaluate the physiological and productive response of two strains of rabbits to early age heat exposure.

\section{MATERIALS AND METHODS}

This study was carried out at the Poultry Physiology Lab, Poultry production Department, Faculty of Agriculture, Ain shams University, Egypt, during the period mid - April to June, 2018.

A total number of 60 unsexed weaned (five weeks of age), rabbits, from both New Zealand White (NZW) and local Baladi (LB) rabbits breeds, were used in the present study. The average initial body weight $500 \mathrm{~g}$ and $457 \mathrm{~g}$ for NZW and LB rabbits, respectively. Rabbits were divided randomly into two treatment groups (heat stressed and control). After an adaptation period of one week, the heat stressed (HS) group was exposed to four hours of high temperature $\left(36^{\circ} \mathrm{C} \pm 1^{\circ} \mathrm{C}\right)$ and relative humidity ( $\mathrm{RH} \%, 55-60 \%)$, for three consecutive days, while the control group was exposed to the normal in door Lab temperature being $\left(28^{\circ} \mathrm{C}\right.$ and $40 \% \mathrm{RH}$ ). The same treatment was repeated after six weeks of age at marketing age, 13 weeks of age. All rabbits were fed ad libitum a commercial pelleted diet, and fresh water was available all times through nipples drinker system. Composition and calculated analysis of the experimental diet is illustrated in Table (1). After the HS period three animals from each group were randomly chosen and slaughtered for blood samples collection.
Blood samples were collected in heparinized tubes, centrifuged (400 $\mathrm{rpm} / \mathrm{min}$ ), then plasma was decanted and stored at $-20^{\circ} \mathrm{C}$ till the biochemical analysis.

\section{Experimental diets}

Table 1. Composition and calculated analysis of the basal diet

\begin{tabular}{|l|l|}
\hline \multicolumn{1}{|c|}{ Ingredients } & \multicolumn{1}{|c|}{$\%$} \\
\hline Clover hay & 30.00 \\
Wheat bran & 26.20 \\
Barley grain & 21.00 \\
Soybean meal (44\% CP) & 18.00 \\
Molasses & 3.00 \\
Limestone & 1.00 \\
Sodium chloride & 0.50 \\
Vitamins \& mineral Permix * & 0.30 \\
\hline Total & 100.00 \\
\hline Calculated chemical composition & \\
Crude protein (CP)\% & 18.72 \\
Ether extract (EE)\% & 2.95 \\
Crude fiber (CF)\% & 13.07 \\
Digestible energy (Kcal/Kg diet) & 2590.00 \\
\hline
\end{tabular}

* Each one $\mathrm{Kg}$ of Premix contains

$150000 \mathrm{IU}$ of Vit., A, $100 \mathrm{mg}$ Vit. E, $21 \mathrm{mg}$ Vit. K3, $10 \mathrm{mg}$ Vit $B_{1}, 40 \mathrm{mg}$ Vit. $B_{7}, 15 \mathrm{mg}$ Vit $B_{6}, 0.1 \mathrm{mg}$ Vit. $B_{12}, 200 \mathrm{mg}$ Niacin, $100 \mathrm{mg}$ Paurtotheric acid $0.5 \mathrm{mg}$ Biotin, $10 \mathrm{mg}$ Folic acid, $5000 \mathrm{mg}$ Choline chloride, $450 \mathrm{mg} \mathrm{Zn,} 600 \mathrm{mg}$. $\mathrm{Mn}, 0.3 \mathrm{mg} \mathrm{Fe}, 50 \mathrm{mg} \mathrm{Cu}, 0.25 \mathrm{~g} .1 .1 \mathrm{mg} \mathrm{Se}$.

\section{Productive performance}

Live body weight, average daily weight gain, feed consumption (FC) and feed conversion ratio (FCR) were recorded for the whole experiment period.

\section{Blood measurements}

Plasma total protein, albumin and globulin were recorded and then albumin: globulin ratio $(A / G)$ was calculated, also, plasma cholesterol, triglycerides, HDL and LDL were determined, by using commercial kits Spectrum Diagnostic kits, Spect.; Crop. For Biotech. S.A.E., Egypt).

*1- 13 denotes to: T3= triiodothyronine (ng/dl); IGF -1 = Insulin- like growth factors; Cort. = Corticosterone $(\mathrm{ng} / \mathrm{dl})$; TP= Total protein $(\mathrm{g} / \mathrm{dl}) ; \mathrm{Alb}=$ Albumin (g/dl); Chol= Cholesterol (mg/dl); Tri-g = Triglycerides $(\mathrm{mg} / \mathrm{dl})$; HDL $=$ high density lipoprotein $(\mathrm{mg} / \mathrm{dl})$; ALT \& AST (u/l); TAC = total antioxidant capacity $(\mathrm{mmol} / \mathrm{ml})$; Creat= creatinine $(\mathrm{mg} / \mathrm{dl})$; Urea $(\mathrm{mg} / \mathrm{dl})$. 
MDA assay according to Mihara et al (1978). Determination of malondialdehyde precursors in tissues by thiobarbituric acid test.

TAC $=$ Total antioxidant capacity, according to Koracevic et al (2001). Method for the measurement of antioxidant activity in human fluids. Thyroid hormones assay by RIA technique according to Britton et al (1975). A strategy for thyroid function tests.

\section{Heat Shock protein determination}

A small specimen $(2 \mathrm{~g})$ form the spleen of each rabbit was immediately dissected, and quickly frozen in liquid nitrogen for latter measurement of HSPS.

RNA isolation and real-time quantitative RTPCR

Total RNA was extracted from quick-frozen liver samples using TRIzol® reagent (Invitrogen Life Technologies, Palo Alto, CA, USA) following the DNase I treatment and purification of total RNA by RNeasy mini kit (Qiagen, Valencia, CA, USA). The RNA quality and quantity were determined using agarose gel electrophoresis and NanoDrop 1000 (Thermo Scientific, Wilmington, DE, USA). Two micrograms of total RNA from fresh-frozen liver were converted into cDNA with oligo (dT)16 primer and SuperScript III reverse transcriptase (Invitrogen Grand Island, NY, USA), as previously described (Kang et al 2017). The best primer pairs were initially selected from several pairs based on PCR product quality and lengths after electrophoresis on a $2 \%$ agarose gel. A portion $(1 \mu \mathrm{l})$ of the cDNA was subjected to a quantitative real time PCR (qRT-PCR) using an ABI prism 7300HT system (Applied Biosystems LLC, Foster, CA, USA) with Power SYBR Green PCR Master Mix (Invitrogen Grand Island, NY, USA). The specific oligonucleotide primers were designed by the PRIMERS3 program (http:// frodo.wi.mit.edu).

Total RNA was extracted from quick-frozen liver samples using TRIzol® reagent (Invitrogen Life Technologies, Palo Alto, CA, USA) following the DNase I treatment and purification of total RNA by RNeasy mini kit (Qiagen, Valencia, CA, USA). The RNA quality and quantity were determined using agarose gel electrophoresis and NanoDrop 1000 (Thermo Scientific, Wilmington, DE, USA). Two micrograms of total RNA from fresh-frozen liver were converted into cDNA with oligo (dT)16 primer and SuperScript III reverse transcriptase (Invitrogen Grand Island, NY, USA), as previously described (Kang et al 2017). The best primer pairs were initially selected from several pairs based on PCR product quality and lengths after electrophoresis on a $2 \%$ agarose gel. A portion $(1 \mu \mathrm{l})$ of the cDNA was subjected to a quantitative real time PCR (qRT-PCR) using an ABI prism 7300HT system (Applied Biosystems LLC, Foster, CA, USA) with Power SYBR Green PCR Master Mix (Invitrogen Grand Island, NY, USA). The specific oligonucleotide primers were designed by the PRIMERS3 program (http:// frodo.wi.mit.edu).

\section{Statistical analysis}

Data were analyzed by two way analysis of variance using the general liner model procedure (SAS, 2006). The model was as follows:

$Y_{i j K}=\mu+S_{i}+T_{j}+(S T)_{i j}+e_{i j k}$

Where:

$\boldsymbol{\mu}=$ Overall mean,

$\mathbf{S}_{\mathbf{i}}=$ Strain effect,

$\mathbf{T}_{\mathbf{j}}=$ Treatment effect,

(ST $)_{\text {ij }}=$ Interaction between strain and Treatment, $\mathbf{e}_{\mathrm{ijk}}=$ Experimental error .

\section{RESULTS AND DISCUSSION}

\section{Growth performance traits}

Effect of early age heat conditioning on productive performance of growing rabbits is presented in Table (2). It is clear from the results that FC was affected by heat treatment. Regarding to the effect of breed, data revealed that there were no significant differences between the two breeds in FC during the growing period. This may be attributed to the adaptive response of rabbits during heat exposure at early age, or could be due mainly to modulation of thyroid gland actively as physiologic response to heat stress adaptation.

Feed consumption was not significantly varited between control group and experimental group (480.083 and 482.125 respectively), while feed conversion and daily gain were better in animals exposed to heat stress than control was $(0.701$ \& 0.566 and 713.260 \&795.65). These results are agreement with Chiericato et al (1995) \& Amici et al (2000). Moreover (NZW) rabbits were butter than (L), the best ones. 
Table 2. Effect of early heat conditioning and breed on average of daily gain, feed consumption and feed conversion of growing rabbits after early - age heat exposure

\begin{tabular}{|c|c|c|c|}
\hline Parameters & $\begin{array}{c}\text { Feed } \\
\text { consumption } \\
(\mathbf{g})\end{array}$ & $\begin{array}{c}\text { Feed } \\
\text { conversion } \\
\mathbf{( g )}\end{array}$ & $\begin{array}{c}\text { Daily } \\
\text { gain } \\
\mathbf{( g )}\end{array}$ \\
\hline Breed: & $115.60^{\mathrm{a}}$ & $3.20^{\mathrm{a}}$ & $36.12^{\mathrm{a}}$ \\
Local (L) & $96.42^{\mathrm{b}}$ & $2.70^{\mathrm{b}}$ & $35.72^{\mathrm{b}}$ \\
NZW (N) & 106.25 & 2.95 & 36.00 \\
Overall & \pm 6.102 & \pm 0.103 & \pm 0.061 \\
SEM & & & \\
Heat stress: & $88.31^{\mathrm{b}}$ & $2.60^{\mathrm{b}}$ & $33.96^{\mathrm{b}}$ \\
Control (C) & $125.01^{\mathrm{a}}$ & $3.30^{\mathrm{a}}$ & $37.88^{\mathrm{a}}$ \\
Heat & 105.91 & 2.95 & 35.92 \\
stress(H) & \pm 6.102 & \pm 0.103 & \pm 0.061 \\
Overall & & & \\
SEM & & & \\
Interaction & & $1.36^{\mathrm{cd}}$ & $35.12^{\mathrm{b}}$ \\
LC & $47.76^{\mathrm{d}}$ & $1.52^{\mathrm{c}}$ & $35.12^{\mathrm{b}}$ \\
LH & $53.38^{\mathrm{cd}}$ & $2.71^{\mathrm{a}}$ & $35.00^{\mathrm{c}}$ \\
NC & $94.85^{\mathrm{a}}$ & $2.01^{\mathrm{b}}$ & $37.00^{\mathrm{a}}$ \\
\hline $\mathrm{NH}$ & $74.37^{\mathrm{b}}$ & & \\
\hline
\end{tabular}

Means, within column in each followed by different superscripts differ significantly $(P \leq 0.05)$.

\section{Blood biochemical paramerters}

The results of blood parameters (TP, ALB., Globulin, $A / G$ ratio) revealed that all plasma profein fractions were insignificantly affected by rabbits strain. However, heat exposure at early age had significant effect on all plasma proteins (Table 3). In this concern, plasma TP, Alb., globulin and $A / G$ ratio were significantly higher in HS- rabbits than control ones. On the other hand, the interaction results showed an interesting results, where plasma TP and Alb., levels were higher in both heat - stressed breeds ( $\mathrm{LH}$ and $\mathrm{NH}$ ) compared to control groups. However, results indicate that the local breed rabbits had significantly higher plasma globulin levels than those of the exotic NZW breed. This support the well-known fact that the local breed has better immunity than NZW rabbits. This results agree with Vendemial et al (1989).

\section{Effect of early - age heat exposure on some plasma hormones concentration}

Table (4) illustrates that plasma tri- iodothyronine (T3), insulin like growth factor (IGF) and corticosterone (cort.) levels were not significantly influenced by the breed of rabbits. However, both IGF and Cort., levels, but not T3, were significantly increased in HS rabbits than the control ones. Consequently, the HS by breed interaction showed significant increases in all hormones level.

Results in Table (5) revealed a significant effect of early age heat exposure on heat shock protein (HSP 70 and HSP 90), expression in spleen tissues, regardless rabbits breed. Both HSPs were significantly higher in heat stressed rabbits than control ones. This may be on early age adaptive response to HS change. Exposure to acute stressful experience can enhance the later ability to acquire new memories about associations between stimuli. Stressful experience can positively affect the subsequent acquisition of associative memories. (Beylin and Shors, 2003). In poultry improving the acquisition of thermotolerance is possible by exposing them to high ambient temperatures during critical periods (first week of life) Yahav and Mc-Murtry, 2001. The results of the our study corroborate the previous reports by illustrating that thermal conditioning has a positive effect on improving thermotolerance acquisition in rabbit in later life, since, the rabbit in both breeds on reexposure to thermal stress at 13 weeks old showed significantly high level of gene expression for heat shock response related genes ,HSP70 and Hsp90 indicating the adaptation of rabbit to high temperature because of pre-conditioning and reducing the stress condition and resulting in high levels of expression. The results of our study demonstrated that, in response to AHS at later life, both hepatic Hsp70 and hsp90 expression increased in thermal conditioned rabbits compared to their relative control. These findings corroborate those of previous studies that elevations of hsp70, and hsp90 mRNA occur in the heart after $2 \mathrm{~h}$ of heat stress, and these factors may act as important markers and protective proteins in response to adverse environmental conditions ( $\mathrm{Yu}$ and Bao. 2008). Also, Wang et al 2014 reported that induction of Hsp70 overexpression suppress heat stress-induced apoptosis of cardiomyocytes in mice.) Increase in hepatic HSP70 gene expression 

parameters of two strains of rabbits

Table 3. Effect of early heat conditioning and breed on plasma total protein fraction of growing rabbits at six weeks of age

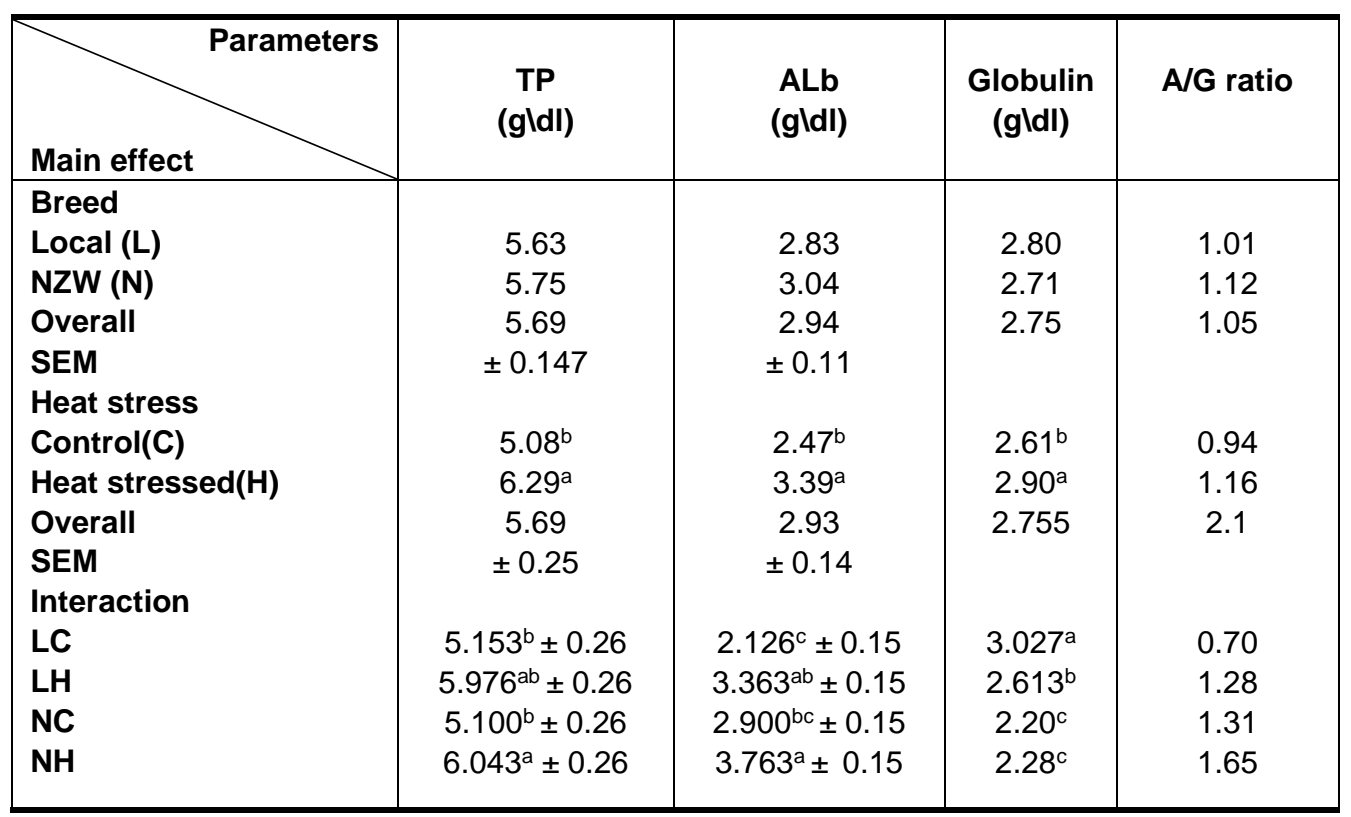

Means, within column in each parameter, followed by different superscripts differ significantly $(P \leq 0.05)$.

Table 4. The effect of early age heat conditioning of rabbits on some plasma hormones concentration

\begin{tabular}{|l|c|c|c|}
\hline Main effect & $\begin{array}{c}\text { T3 } \\
\text { (ng/dl) }\end{array}$ & $\begin{array}{c}\text { IGF } \\
\text { (ng/dl) }\end{array}$ & $\begin{array}{c}\text { Cort. } \\
\text { (ng/dl) }\end{array}$ \\
\hline Breed & 2.20 & $22.40^{\mathrm{b}}$ & $2.02^{\mathrm{b}}$ \\
Local (L) & 2.07 & $25.65^{\mathrm{a}}$ & $2.27^{\mathrm{a}}$ \\
NZW (N) & 2.13 & 24.03 & 2.15 \\
Overall & \pm 0.162 & \pm 1.17 & \pm 0.115 \\
SEM & 2.18 & $20.07^{\mathrm{b}}$ & $1.98^{\mathrm{b}}$ \\
Heat stress & 2.20 & $25.09^{\mathrm{a}}$ & $2.20^{\mathrm{a}}$ \\
Control(C) & 2.18 & 22.58 & 2.09 \\
Heat stressed(H) & \pm 0.31 & \pm 2.4 & \pm 0.23 \\
Overall & & $20.52^{\mathrm{d}} \pm 2.4$ & $1.43^{\mathrm{d}} \pm 0.23$ \\
SEM & $2.41^{\mathrm{bc}} \pm 0.32$ & $23.55^{\mathrm{b}} \pm 2.4$ & $2.42^{\mathrm{b}} \pm 0.23$ \\
Interaction & $2.55^{\mathrm{b}} \pm 0.32$ & $22.31^{\mathrm{c}} \pm 2.4$ & $1.93^{\mathrm{bc}} \pm 0.23$ \\
LC & $3.05^{\mathrm{a}} \pm 0.32$ & $26.37^{\mathrm{a}} \pm 2.4$ & $3.23^{\mathrm{a}} \pm 0.23$ \\
LH & $2.81^{\mathrm{ab}} \pm 0.32$ & & \\
NC & & & \\
NH & &
\end{tabular}

Means, within column in each parameter, followed by different superscripts differ significantly $(P \leq 0.05)$. 
Table 5. Effect of early age heat exposure of growing rabbits on heat shock protein expression in liver tissue samples

\begin{tabular}{|l|c|c|}
\hline \multicolumn{1}{|c|}{ Parameters } & Hsp 90 \\
Main effect & & \\
\hline Local (L) & & \\
NZW (N) & $0.859 \pm 0.082$ & $1.031 \pm 0.056$ \\
Overall & $0.681 \pm 0.021$ & $1.014 \pm 0.129$ \\
SEM & 0.77 & 507.51 \\
Heat stress & & \\
H & $1.0016 \pm 0.38^{\mathrm{a}}$ & $1.0036 \pm 0.0614^{\mathrm{a}}$ \\
C & $0.859 \pm 0.047^{\mathrm{b}}$ & $1.0315 \pm 0.0327^{\mathrm{b}}$ \\
Overall & 0.9303 & 1.0175 \\
& & \\
\hline
\end{tabular}

Means, within column in each parameter, followed by different superscripts differ significantly $(P \leq 0.05)$.

A)

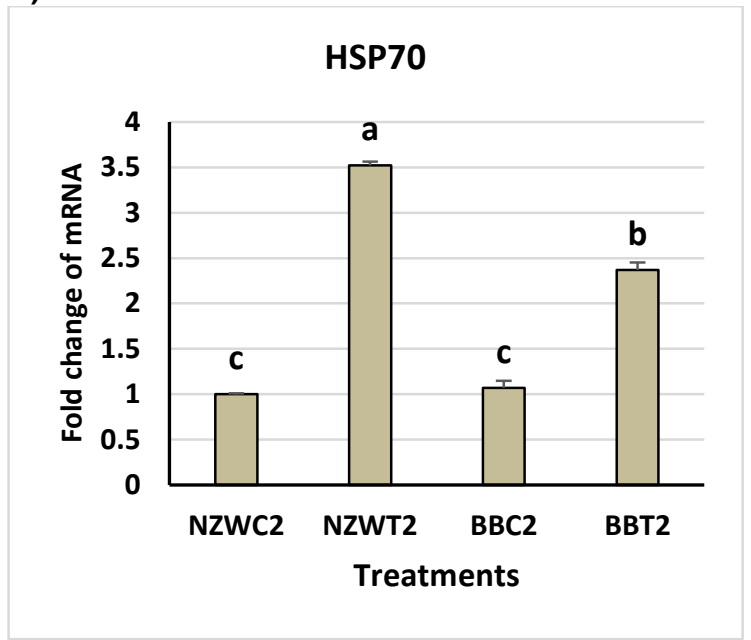

B)

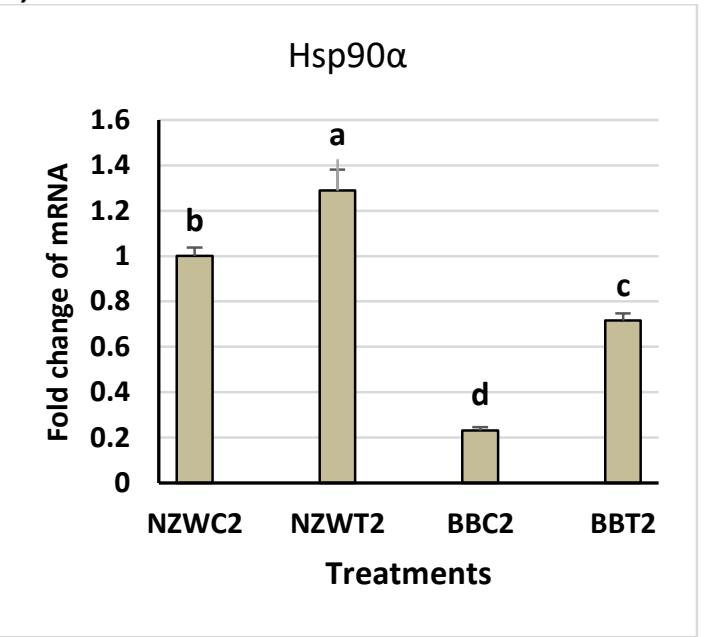

Fig. 1. Heat shock protein (HSP) gene expression in liver of NZW and Baladi Black rabbits breed at 13 weeks of age. A. HSP 70 alpha and B. HSP 90,a, b Means with different superscripts differ significantly $(\mathrm{P}<0.05)$

compared with that in the control group BBC, this activation may be is a kind of cytoprotective mechanism and that further permits the cells to survive, this finding has been confirmed by previous studies in rabbit testis (Pei et al 2011) in broilers (Zulkifli et al 2014) in chicken (Cedraz et al 2017) in mice (Wang et al 2014) and in fish (BenítezDorta et al 2017). Enhanced Hsp70 expression may be a response to stressful condition, and may enhance cell survival by protecting proteins from degradation and facilitating their refolding (Yu and
Bao 2008) moreover, this up-regulation of hsp70 can block apoptosis through the inhibition of several caspase proteins (Beere, 2004) and naturalize damaged proteins before initializing the apoptotic process.

\section{CONCLUSIONS}

It is concluded that early age heat exposure of weaning rabbits could be used as an alternative tool to alleviate the negative impact of heat stress at older age. 


\section{REFERENCES}

Abd El-Halim S.A. 2003. Comparative studies on the performance of some genotypes of rabbits. M.Sc. Thesis, Fac. of Agric., Cairo Univ., Egypt. $54 \mathrm{p}$.

Amici A., Franci O., Mastroiacono P., Merendino N., Nardini M. and Tomassi G., 2000. Short term acute heat stress in rabbits. Functional, metabolic and immunological effects on plasma testosterone, cortisol, T3 and T4 levels in the growing rabbit. In: Proc. World Rabbit Congress, Oregon State Univ., Corvellis, 1, 447-455.

Beere H.M. 2004. "The stress of dying": the role of heat shock proteins in the regulation of apoptosis. US National Library of Medicine National Institutes of Health. 117(13), 2641-2651.

Benítez-dorta V., Caballero M.J., Betancor M.B., Manchado M., Tort I., Torrecillas S., Zamorano M.J., Izquierdo M. and Montero D. 2017. Effects of thermal stress on the expression of glucocorticoid receptor complex linked genes in senegalese sole (solea senegalensis): acute and adaptive stress responses. US National Library of Medicine National Institutes of Health. 252, 173-185.

Beylin A.V. Shors 2003. Glucocorticoids are necessary for enhancing the acquisition of associative memories after acute stressful experience. Jan; 43(1), 124-131.

Britton K.E., Quin V.C., Brown B.L. and Edkins R.P. 1975. A strategy for thyroid function tests. Brit. Med. J. III, 350-356.

Cedraz, Mizutani N, Nabe T. and Yoshino S. 2017. Topical ocular treatment with monoclonal antibody Fab fragments targeting Japanese cedar pollen Cry j 1 inhibits Japanese cedar pollen-induced allergic conjunctivitis in mice. US National Library of Medicine National Institutes of Health. 798, 105-112.

Chiericato G.M, Boiti C. and Ravarotto L. 1995. Effect of heat stress and age on growth performance and endocrine status of male rabbit. World Rbbits Sci., 3(3), 125-131.

Fernandez C.J. and Cervera C. 2010. Nutrition and climatic environment. In: de Blas, C. and Wiseman J. (ed). Nutrition of the rabbit, $2^{\text {nd }}$ Ed. CABI Int., Wallington UK, pp. 267-284.

Gonzalez R.R., Kluger M.J. and Hardy J.D. 1971. Partitional Calorimetr of New Zealand White rabbit at air temperature $5-35$ degrees ${ }^{\circ} \mathrm{C}$. J. of Applied Physology, 31(5), 728-735.
Hartl F.U. 1996. Molecular chaperones in cellular protein folding. Nature, 381, 571-580.

Koracevic D., Koracevic G. and Csic V. 2001. Method for the measurement of antioxidant activity in human fluids. J. Clin. Pathol., 54(5), 356-364.

Marai I.F.M. and Ayyat M.S. Gabr H.A. and Abdel-Monem U.M. 2001. Effect of summer heat stress and its amelioration on production performance of New Zealand White adult female and male under Egyptian conditions. $6^{\text {th }}$. World Rabbit Congress, Toulouse 2, 197-208.

Mihara M. and Uohiyama M. 1978. Determination of malondialdehyde precursors in tissues by thiobarbituric acid test. Anal. Biochem., 86, 271-278.

Mori K., Tetsushi K., Hiderou Y., Hideki Y. and Takashi Y. 1996. Signalling from endoplasmic reticulum to nucleus: transcription factor with a basic-leucine zipper motif is required for the unfolded protein-response pathway. Sci. Limited Genes to Cells 1, 803-817.

Morimoto R.I., Tissieres A. and Georopoulos C. 1990. Stress protein in biology and medicine. Cold Spring Harbor, New York. USA, National Library of Medicine National Insitutes of Health 346(6286), 710 p. ISSN 0028-0936.

Sakr O.G. 2005. Effect of ambient temperature on the behavior and the productive performance of rabbits. M.Sc. Thesis, Fac. of Agric., Cairo University, Cairo, Egypt. pp. 95-97.

SAS 2006. Statisical Analysis System, SAS User's Guide Statisitcs. SAS Institute Inc. Editors, Cary. NC.

Vendemiale G., Altomare E., Grattagliano I. and Albano O., 1989. Increased levels of glutathione and malondialdehyde after acute ethanol ingestion in humans. J. of Hepatology. 9(3), 359-365.

Wang Y., Pierre M.J., Fatih P., Janusl K., Yannick B. and Parakash N. 2014. Organic polymorphs one compound based crystals with molecular conformation and packing dependent luminnerscent properties. Adv. Mater 2014, 26, 6168-6173.

Yahav and Mc-Murtry 2001. Thermotolerance acquisition in broiler chickens by temperature conditioning early in life the effect of timing and ambient temperaturey. Poultry Sci., 80(12), 1662-1666. 
Yanzhong P., Xiaoya S., Aaron L., Heng W., Lidong C. and Jeffrey S. 2011. Materials science, california institute of technology, pasadena, Ca 91125, USA. Key Laboratory of Materials for Energy Conversion, Shanghai Institute of Ceramics, Shanghai 200050, 2011. China. Convergence of Electronic Bands for High Performance Bulk Thermoelectrics. Adv. Mater., 23, 5674-5678.

Jsnyder@Caltech.Edu.10.1038/Nature09996.
Yu J. and Bao E. 2008. Effect of Acute Heat Stress on Heat Shock Protein 70 and Its Corresponding Mrna Expression in the Heart, Liver, and Kidney of Broilers. Asian-Aust. J. Anim. Sci., 21(8), 1116-1126.

Zulkifi H.K.A. and Awan D. 2014. Analysis faktor - faktor penyebab masalah putus obat pada program kontrol tuberkulosis di wilayah kerja puskesmas gerung lombok barat. National Accredited, 8, 2. 


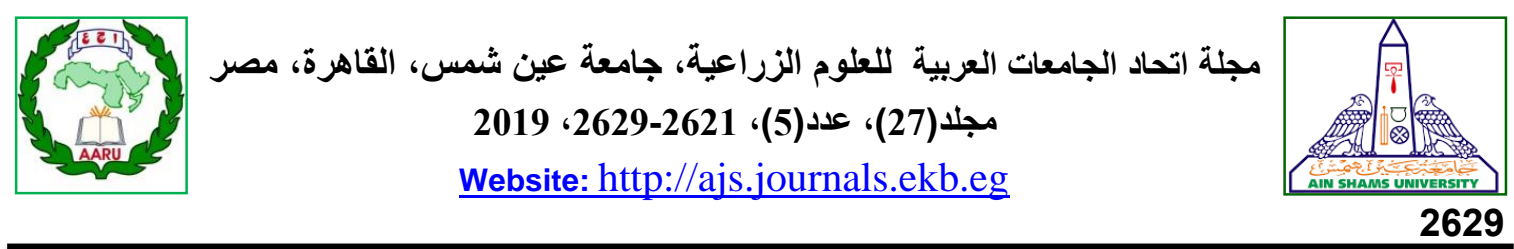

تأثير التهيئة الحرارية المبكرة على الأداء الانتاجى وبعض قياسات الام فى سلالتين من الأرانب الانتاجت

[209]

$$
\begin{aligned}
& \text { صفاء عزت هاشم1" - ابراهيم الوردانى1 } 1 \text { - أحمد جلال } 1 \text { - محمود مدكور2 } 2
\end{aligned}
$$

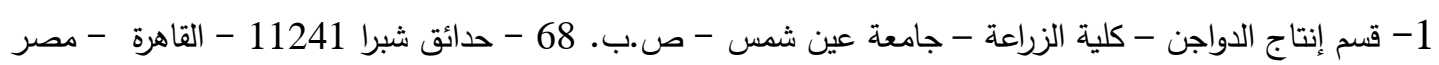

$$
\begin{aligned}
& \text { 2- قسم الإنتاج الحيواني - المركز القومى للبحوث - الدقى - الجيزة - مصر كراج }
\end{aligned}
$$

*Corresponding author: Safaaezzat3@gmail.com

Received 11 October, 2019

Accepted 1 January, 2020

وتوضح النتائج وجود زيادة معنوية فى الزيادة

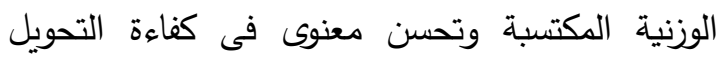

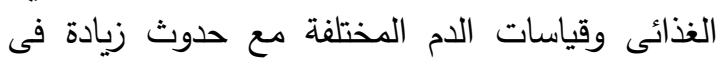

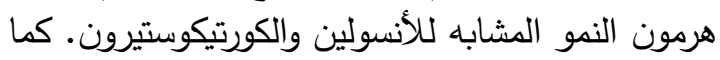

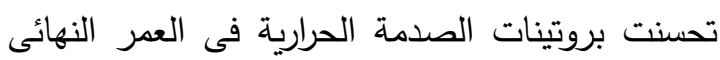

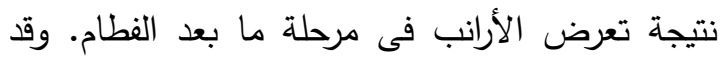

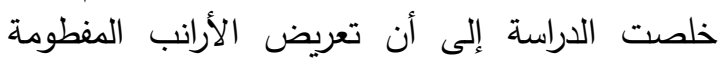

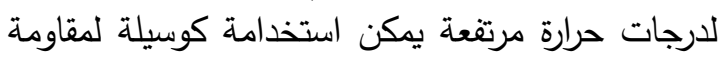

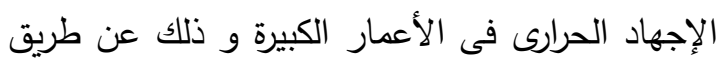

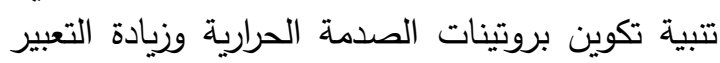

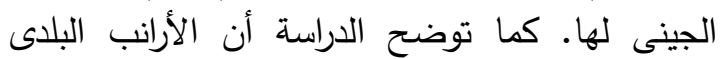
كانت أكثر مقاومة للإجهاد الحرارى عن النئ النيوزلندى الإنى الأبيض.

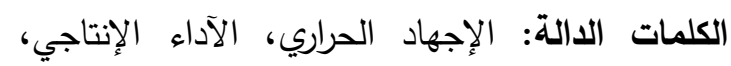
بروتينات الصدمه الحرارية، قياسات الدم، الأرانب الأب الأباد
اجريت هذه الدراسة على سلالتين من الأرانب النامية وذلك بهدف تقييم التأثيرات الفسيولوجيه الناتجة

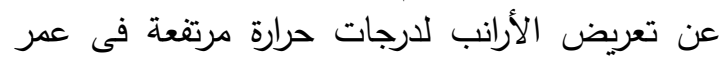

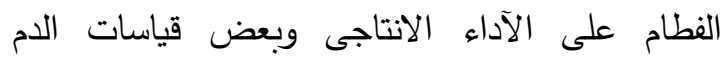
وبروتينات الصدمة الحرارية.

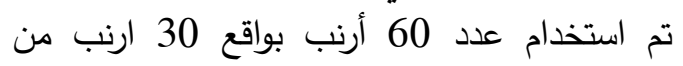

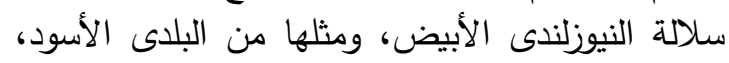

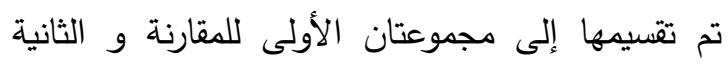
عرضت بعد الفطام لدرجة حرارة مرتفعة (36 (1+1 درجة

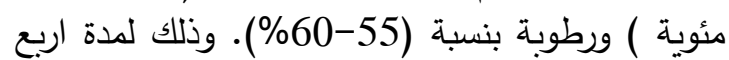
ساعات يوميا ولمدة ثلاث أيام متتالية. وفى نهاية التهاية

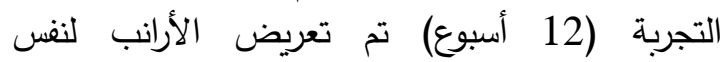

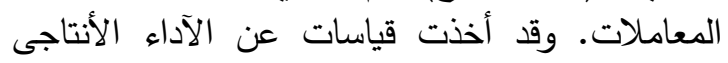

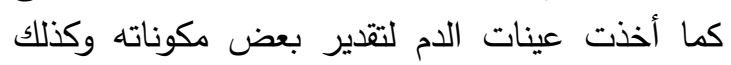

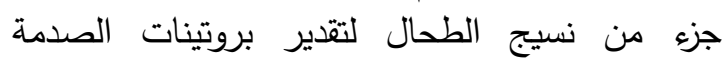
الحرارية 70و 90 كليو دالتون. 